\title{
Giant Intracranial Dermoid Cyst: Case Report and Review of the Literature on Intracranial Dermoids and Epidermoids
}

\author{
NEIL R. MILLER AND MELVIN H. EPSTEIN
}

SUMMARY: A 45-year old man was referred to the Johns Hopkins Hospital with a seven-year history of repeated episodes of light-headedness, increasing irritability and forgetfulness. Examinations revealed a right superior, incongruous quadrantanopsia. EEG showed an abnormality in the left temporal lobe, and a cerebral angiogram outlined an avascular mass in the left cerebral hemisphere. At operation, the

RÉSUMÉ: Un homme de 45 ans est référé à l'Hôpital Johns Hopkins avec une histoire évoluant depuis 7 ans d'épisodes répétés de vertige, d'irritabilité et d'oublis. L'examen a révélé une quadrannopsie incongrue supérieure droite et l'EEG montrait une anomalie du lobe temporal gauche. Finalement, un angiogramme cérébral démontrait une masse avasculaire dans l'hémisphère cérébral gauche. A l'opération, nous avons patient was found to have a giant dermoid cyst involving the left frontal, temporal and parietal lobes. Over the last 30 years we have encountered only 6 cases of intracranial epidermoids and 3 cases of intracranial dermoids. These cases are cited, and a discussion of the embryology, histology, clinical characteristics, and treatment of these lesions with a review of the literature is undertaken.

trouvé chez le patient un kyste dermoide géant impliquant les lobes frontal, temporal et partiétal gauches. Depuis les 30 dernières années, nous avons rencontré seulement 6 cas d'épidermoide intracrânien et 3 cas de dermoide intracrânien. Ces cas sont cités, et une discussion sur l'embryologie, l'histologie, les caractéristiques cliniques, et le traitement de ces lésions, ainsi qu'une revue de la littérature, sont inclues.
From the Wilmer Ophthalmological Institute and the Department of Neurosurgery, The Johns Hopkins Hospital, Baltimore, Maryland 21205.

Reprint requests to Neil R. Miller, MD, Wilmer Institute, Johns Hopkins Hospital, 601 N. Broadway, Baltimore, Maryland 21205.

\section{INTRODUCTION}

Intracranial dermoid cysts are rare lesions, accounting for less then $1 \%$ of all intracranial tumors (Cushing, 1932; Rand and Reeves, 1943; Brock and Klenke, 1931; Bogdanowicz and Wilson, 1972). These masses most often are located in the posterior fossa (Dandy, 1942; MaCarty et al., 1959); however, they may occur anywhere within the cranial vault and may attain large proportions. The patient reported here presented with temporal lobe seizures and a homonymous, incongruous, visual field defect. At operation, a giant dermoid cyst involving the left frontal, parietal and temporal lobes was discovered.

\section{CASE REPORT}

A 45-year-old Italian-American male was admitted to the Johns Hopkins Hospital complaining of recurrent dizzy spells. Seven years prior to admission the patient first experienced an episode during which he suddenly lost consciousness and became pale and unresponsive. He was neither incontinent nor did he exhibit involuntary movements. He regained consciousness after several minutes and did not experience any post-ictal lethargy or headache. He was immediately taken to a nearby hospital where an EEG and a lumbar puncture were performed and reported to be normal. The patient was placed on diphenylhydantoin; however, several months later, following two similar episodes, primidone was added to his regimen.

At the same time, the patient began to experience frequent 
episodes of light-headedness occurring three to four times a day and lasting about thirty seconds. The attacks were unrelated to activity, posture, meals or time of day and were not preceded by hyperventilation. Vertigo never occurred during the episodes, and consciousness was never lost.
During the year prior to admission, the patient became increasingly irritable and forgetful, and the episodes of light-headedness increased in frequency, occurring up to seven times a day. The patient was finally referred to the Johns Hopkins Hospital for evaluation.

On admission, general physical

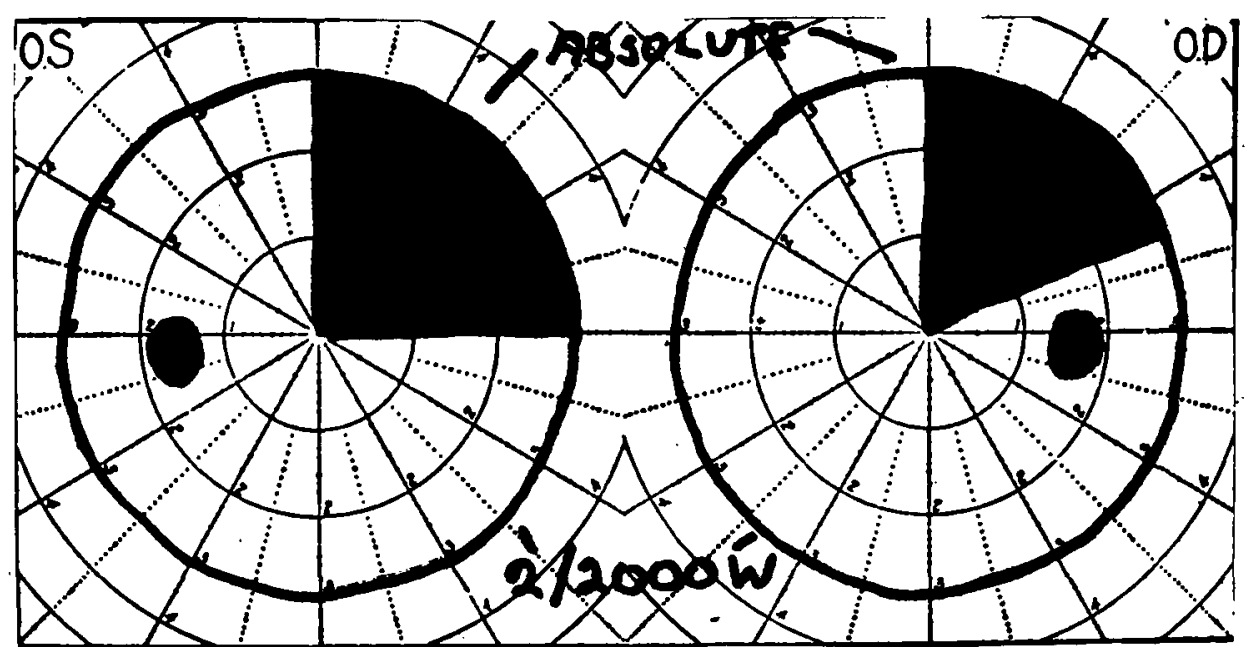

Figure 1-Visual field on admission to hospital. An absolute, incongruous, right superior quadrantanopsia is present.

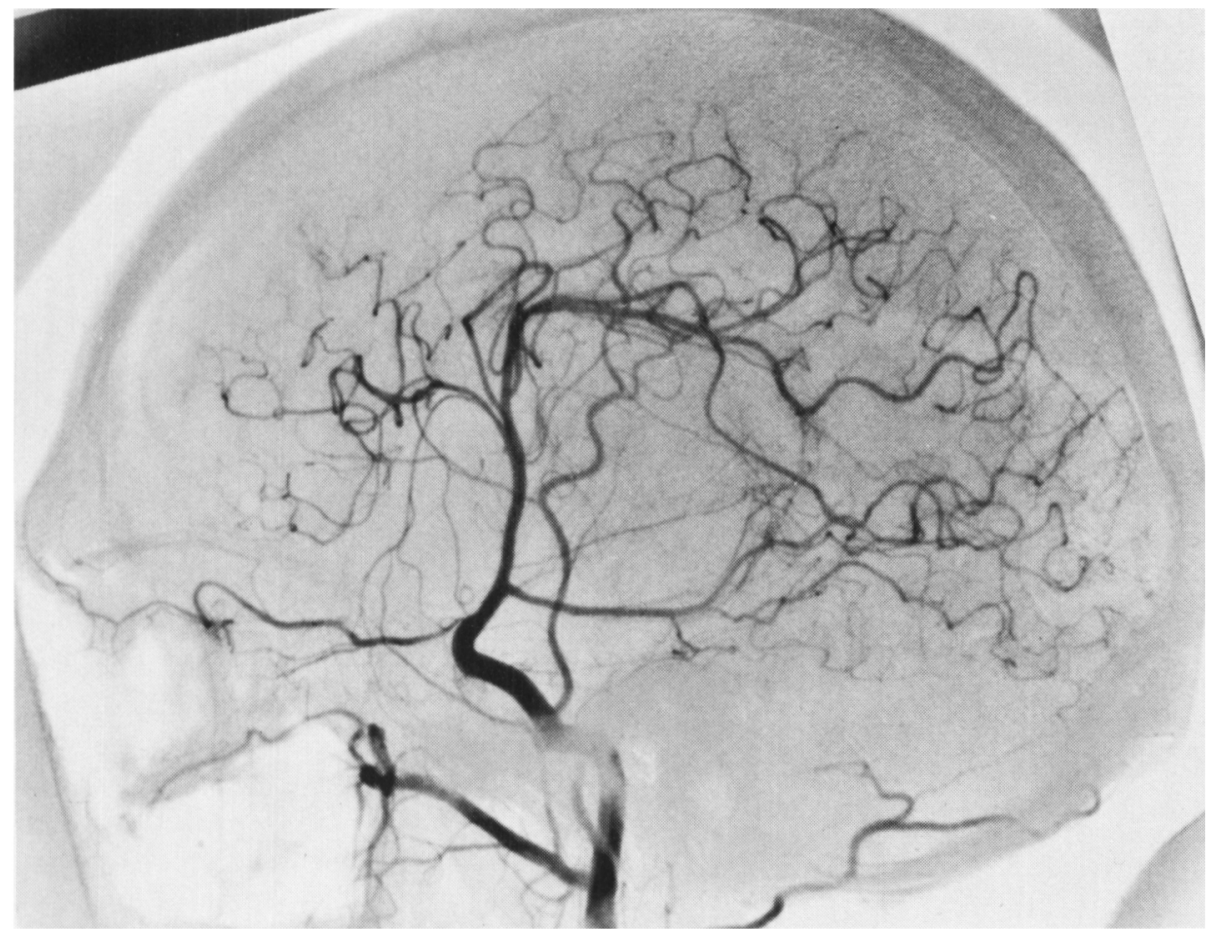

Figure 2-Left carotid arteriogram (lateral view). The left middle cerebral artery is markedly stretched and elevated by a large mass in the left cerebral hemisphere. examination was entirely normal. Neurological examination revealed mild generalized weakness of the right upper limb; however, the muscle stretch reflexes were symmetrically active in all extremities. Ophthalmologic examination revealed best-corrected visual acuity of 20/20 in each eye. Ductions and versions were full. The pupils were equal and normally reactive to light and near. The optic discs were normal. Examination of the visual fields revealed an incongruous, right superior quadrantanopsia (Fig. 1).

An EEG showed left temporal slowing with rare slow-wave spikes. A brain scan was interpreted as normal. Cerebral angiography revealed marked elevation of the left middle cerebral artery with a $1 \mathrm{~cm}$. left-to-right shift caused by a large avascular mass in the left temporal and frontal lobes (Figs. 2 and 3).

A left fronto-temporal craniotomy was performed. The brain was observed to be quite tense, and a large mass was palpable within the left temporal lobe which extended into the left frontal lobe. The anterior aspect of the inferior temporal gyrus was resected, revealing a welldefined, encapsulated tumor mass (Fig. 4). The capsule was incised, and a glistening cheesy material was observed within the cavity. The material was evacuated with a curette, and particles of hair were found to be incorporated within it. The tumor extended from the base of the temporal fossa three-quarters of the way to the falx superiorly and across to the occipital lobe about 2 to $3 \mathrm{~cm}$. posterior to the Vein of Labbé, anteriorly to the anterior aspect of the frontal fossa, and across the sylvian fissure into the frontal lobe (Fig. 5.).

The tumor cavity was thoroughly irrigated, and an attempt was made to strip off the tumor capsule. This was accomplished in the area of the middle fossa, but within the farthest confines of the mass, it was apparent that capsule was tightly adherent to normal brain substance and could not be removed. The dura was therefore closed, the bone flap wired into place, and the operation terminated.

Pathologic examination of the wall 
of the mass revealed dense connective tissue lined by stratified squamous epithelium (Fig. 6). Some areas of the wall contained hair shafts (Fig. 7). The material within the cavity consisted of desquamated epithelium, acellular keratinized debris, and particles of hair.

Post-operatively, the patient recovered, and, although the visual field defect persisted, the remainder of the patient's symptomatology disappeared completely. He has been followed for one year without evidence of recurrence.

\section{DISCUSSION}

Dermoid cysts are among the rarest of intracranial mass lesions. Although some authors have estimated their incidence as $0.1 \%$ to 0.7\% (Cushing, 1932; Brock and Klenke, 1931; Rand and Reeves, 1943), others (Dandy, 1942; Russell and Rubenstein, 1971) believe that their occurrence is so infrequent that a true incidence cannot be determined. Although Verratus is credited with the first description of an intracranial dermoid cyst in 1745 (Critchley and Ferguson, 1928), it was Cruveilhier (1829) who described a lesion at the base of the brain which, because its appearance was "like a pearl of the finest water," he called a "tumour perlee - pearly tumor." Muller (1838) found that many of these lesions. contained crystals of cholesterin and proposed the term "cholesteatoma." Although Virchow (1855) and others discarded this term in favor of the more descriptive term of Cruveilhier, "cholesteatoma" has nevertheless been used synonymously with "epidermoid" by some authors (Love and Kernohan, 1936; Rand and Reeves, 1943; Fox and South, 1965), thus creating great confusion between these lesions and the "true" cholesteatomas originating in the middle ear.

Critchley and Ferguson (1928) and Dandy (1942) first recognized the existence of two distinct lesions, dermoids and epidermoids; however, as late as 1956, Tytus and Pennybacker continued to use the term "pearly tumor" to describe both tumors. More recently, Russell and
Rubenstein (1971) have stressed the importance of distinguishing between dermoids and epidermoids on histologic, as well as clinical, grounds.

Pathology. Epidermoids, the true pearly tumors of Cruveilhier, are composed of dense collagenous tissue lined by stratified squamous epithelium to form a cystic structure, with the cyst cavity filled with acellular, keratinaceous debris (Fig. 8 ). The structure of dermoids is similar to that of epidermoids except for the presence of pilo-sebaceous apparati - hair follicles and secretory

glands - in the wall of the cyst as well as particles of hair within the cyst cavity (Fig. 9). Epidermoids expand by progressive exfoliation of keratinaceous debris into the cyst cavity, while dermoids enlarge by exfoliation of debris, as well as by deposition of hair and secretory material into the cyst cavity.

Embryology. It is generally believed that both dermoids and epidermoids are derived from inclusion of ectodermal elements during closure of the neural groove, a process which occurs between the third and fourth weeks of embryogenesis,

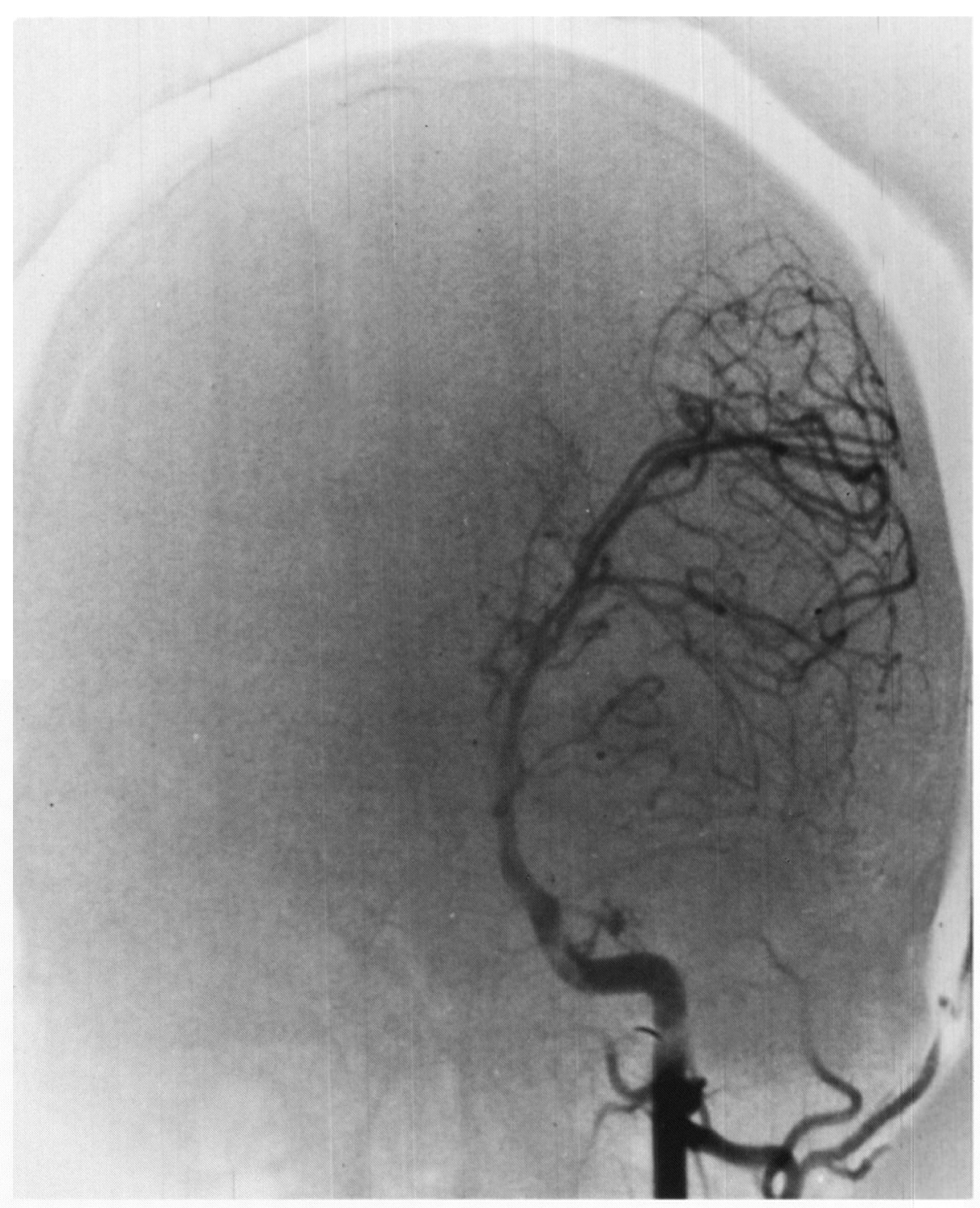

Figure 3-Left carotid arteriogram (A-P view). The left middle cerebral artery shows a marked left-to-right shift caused by a large avascular mass in the left cerebral hemisphere. 


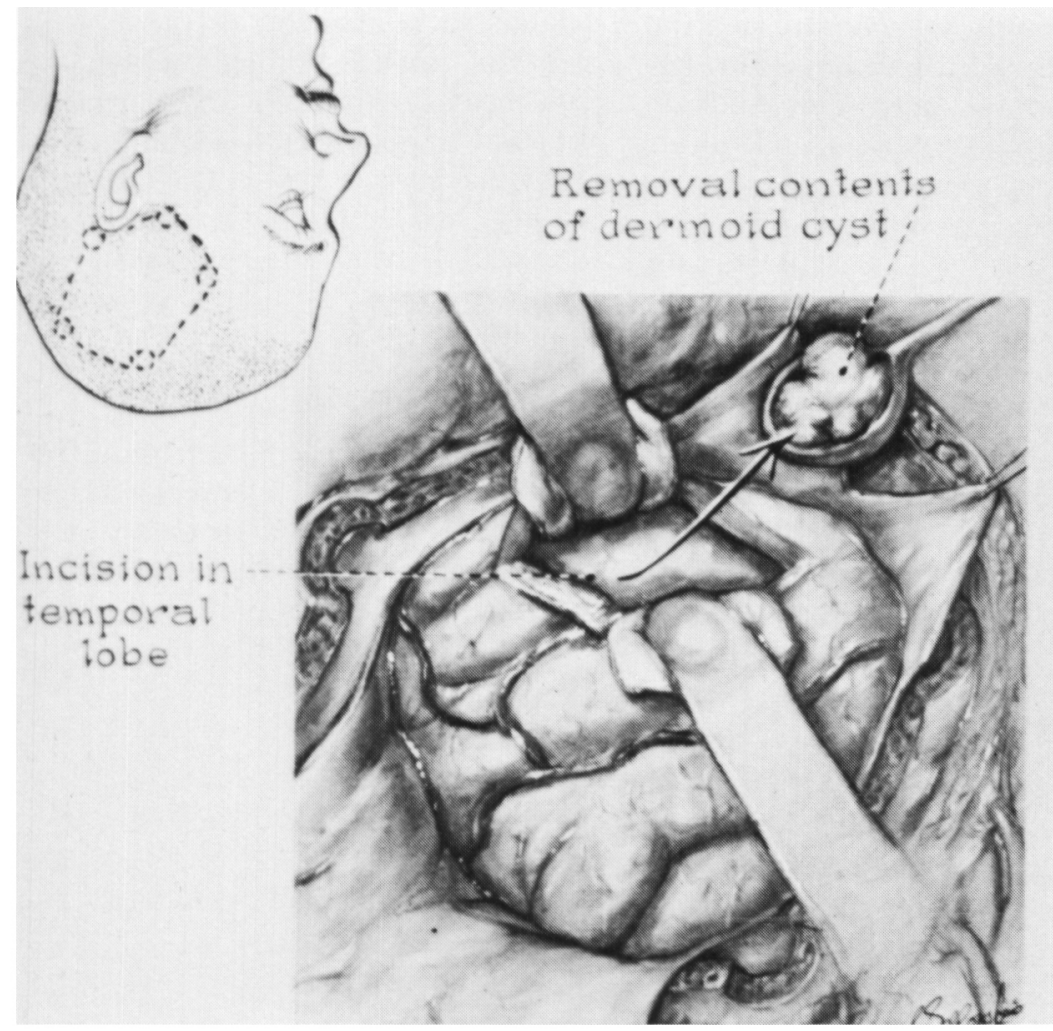

Figure 4-Drawing of the external appearance of the dermoid cyst at operation. The patient's head position is shown in the top-left corner of the figure.

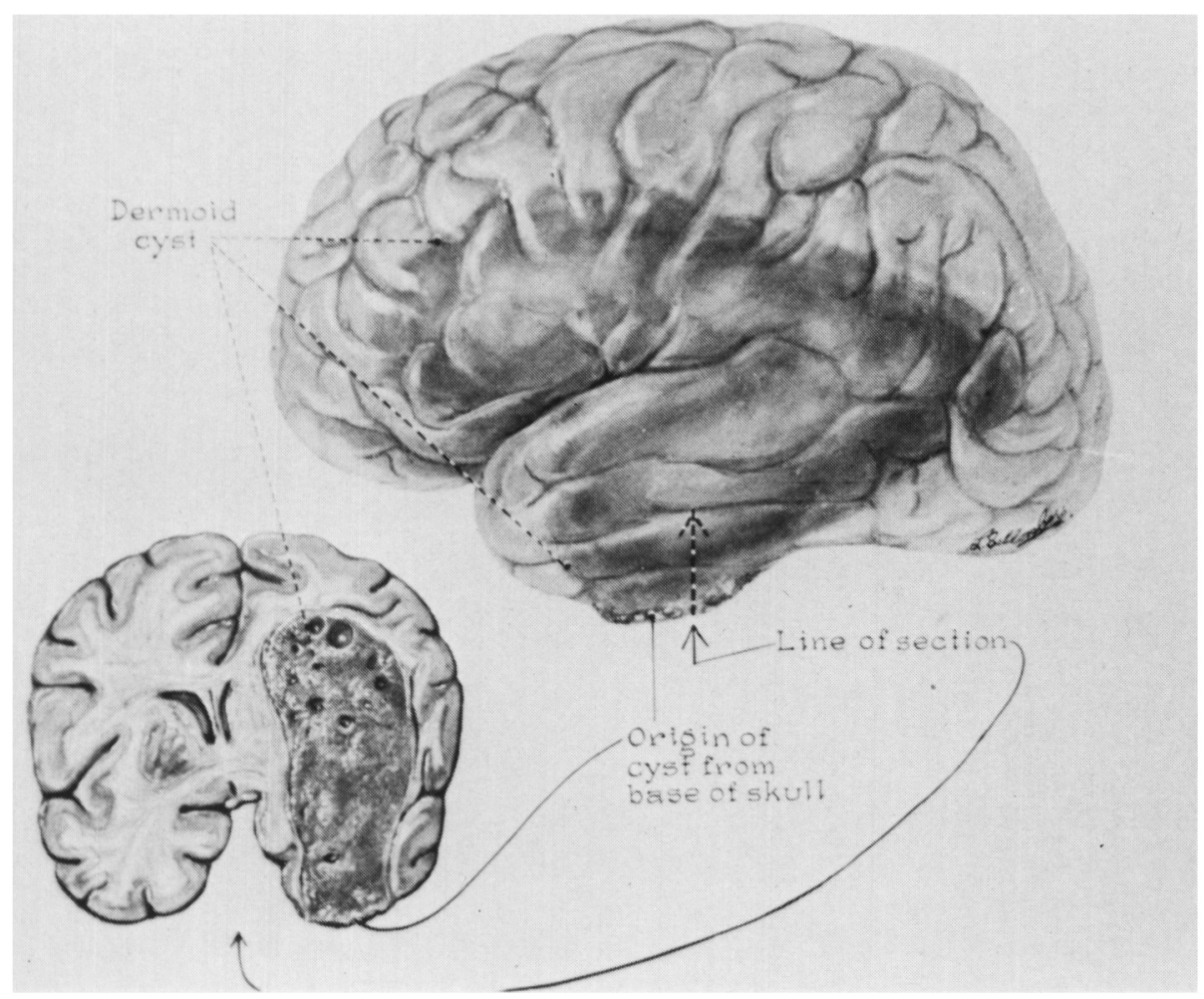

Figure 5-Drawing of the extent of the dermoid cyst with its presumed site of origin from the base of the temporal lobe. and results in a heterotopia of the elements, with the displaced cells lying near the mid-saggital plane, associated with either a persistent defect in closure of overlying skin and bone, or with a congenital dermal sinus. Since both dermoids and epidermoids may occur laterally, it has been postulated that inclusions also occur during formation of the secondary cerebral vesicles between the fourth and fifth weeks of gestation.

Although Bostroem (1897) originally advanced the hypothesis that both the tissue-depth of the ectodermal anlage and the age of the embryonal layer involved were the major factors which determine whether the aberrant tissue will ultimately develop into a dermoid or epidermoid, Toglia and co-workers (1965) believe that it is the presence or absence of mesodermal tissue which is the sole determining factor. They suggest that when ectoderm alone is sequestered during embryogenesis, the trapped cells will develop into epidermoid rests with a histologic appearance determined by the site of origin of the ectoderm; however, if the developing ectoderm is in direct contact with mesodermal tissue, the ectodermal structure which results will be a dermoid.

Occurrence. Although absolute differentiation between epidermoids and dermoids is generally made on the basis of histology, these lesions do differ from each other in some respects.

Intracranial epidermoids have been encountered more frequently than dermoids. The ratio of epidermoids in most studies ranges from $3: 1$ to $25: 1$ with most authors finding a ratio of about 4:1 (Dandy, 1942; MaCarty et al., 1959; Fleming and Botterell, 1959; Keville and Wise, 1959). At the Johns Hopkins Hospital, we have encountered six intracranial epidermoids and three dermoids over the past thirty years (Tables 1 and 2). Prior to this time Dandy (1942) reported observing twenty-five epidermoids and one dermoid (although only ten of these cases are well-documented). Six patients with epidermoids confined to the skull and epidural structures 
have also been observed by us but will not be discussed in the context of this paper.

Epidermoids may become symptomatic at any age; however, most authors have found a peak incidence in the fourth or fifth decade (Brock and Klenke, 1931; Fleming and Botterell, 1959; Ulrich, 1964). The average age of patients with intracranial epidermoids in our series was fortytwo years (Table 1). Dermoids usually become symptomatic in younger individuals, generally within the first three decades of life (Brock and Klenke, 1931; Love and Kernohan, 1936). The patient reported here developed his symptomatology at age thirty-seven, somewhat older than the average, and it is of note that the two other patients with intracranial dermoid cysts whom we have observed also developed their symptomatology later in life (ages fortythree and fifty-two years, Table 2).

Typical of both epidermoids and dermoids is the slow growth pattern with a characteristically long duration from onset of symptomatology to diagnosis. Most studies have shown that the duration to diagnosis varies from two to ten years, with the average being about eight years (Love and Kernohan, 1936; Tytus and Pennybacker, 1956; Fleming and Botterell, 1959; Ulrich, 1964; Zylak et al., 1969). Our patient's symptoms had been present for seven years before the proper diagnosis was made. The average duration of symptoms in our series is two years for patients with epidermoids (Table 1) and five years for dermoids (Table 2).

Symptomatology. Although dementia and seizures have been emphasized as common symptoms in patients harboring intracranial epidermoids and dermoids (Brock and Klenke, 1931; Ulrich, 1964), our experience as well as that of others suggests that the symptoms encountered in these patients depend solely upon the location, tumor depth, and size of the mass, and that no specific symptomatology predominates (Tables 1 and 2).

Location. Whereas epidermoids are most commonly found in the cerebellopontine angle and in the

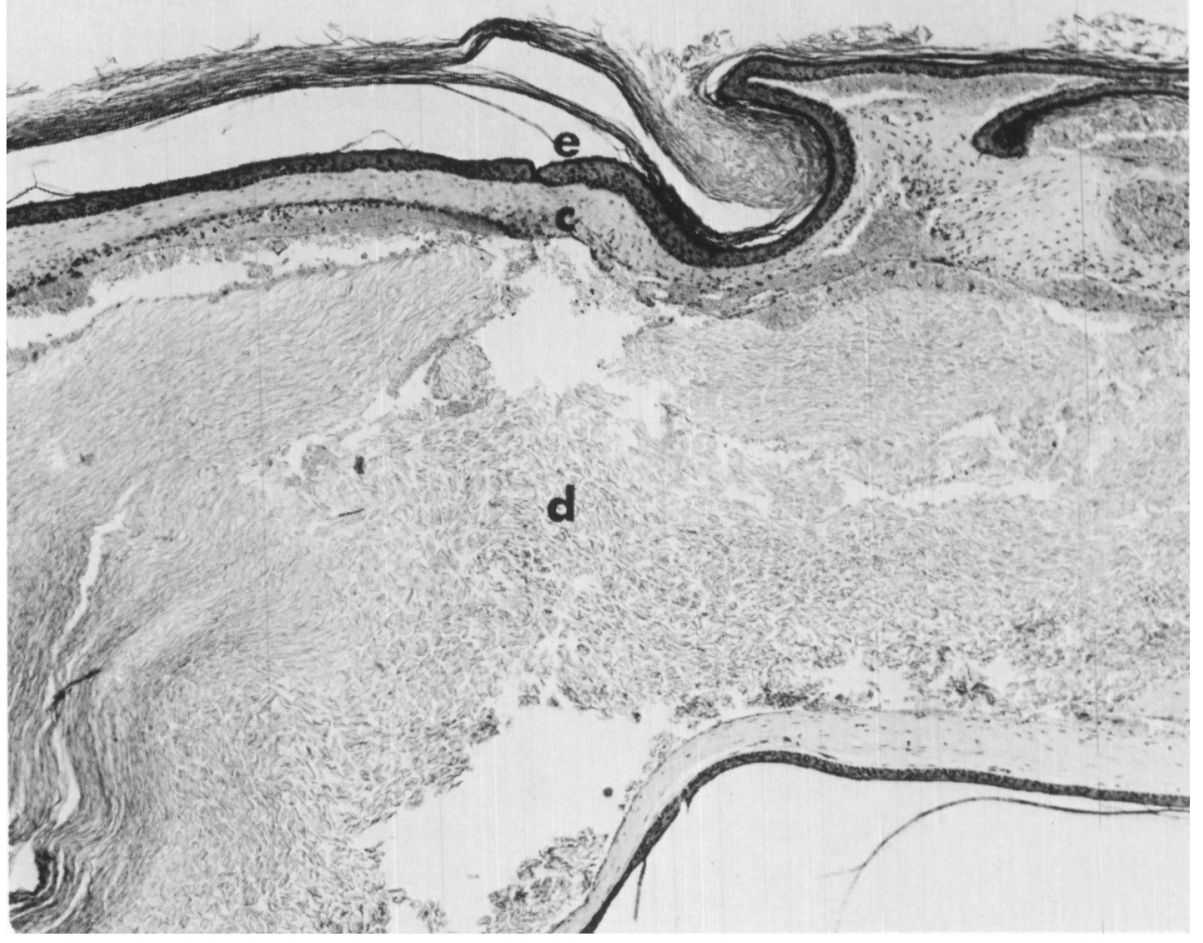

Figure 6-Dermoid cyst showing epithelial lining (e), dense connective tissue (c) of the cyst wall and extensive deposition of acellular, keratinized debris within the cyst cavity (d) (H \& E, X45).

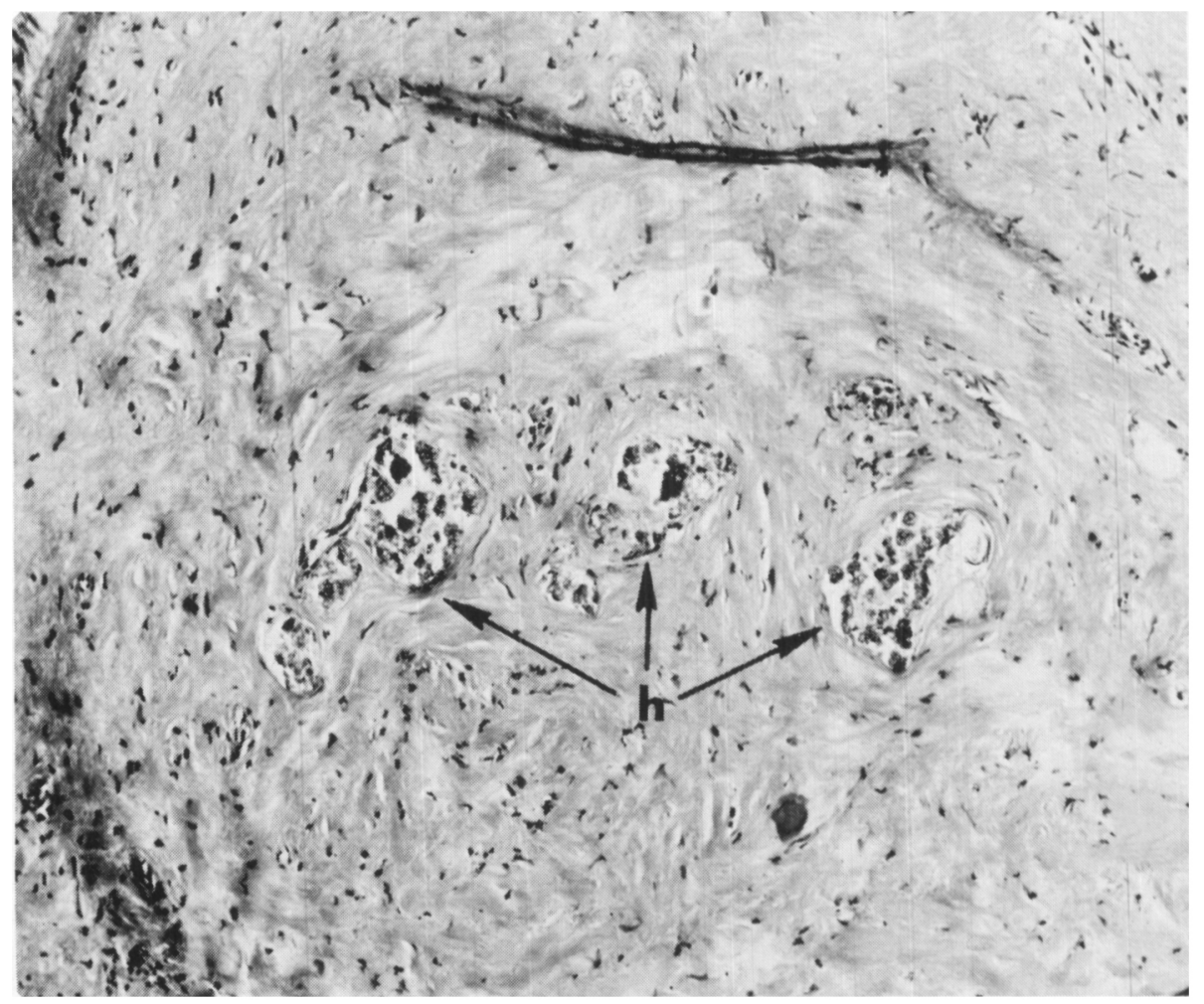

Figure 7-Portion of the wall of the dermoid cyst containing three structures with multiple hair shafts (h) (H \& E, X 145). 
TABLE 1

\begin{tabular}{|c|c|c|c|c|c|c|c|}
\hline Case No. & $\begin{array}{l}\text { Age At } \\
\text { Onset }\end{array}$ & Sex & Symptomatology & $\begin{array}{l}\text { Duration to } \\
\text { Diagnosis }\end{array}$ & Location & $\begin{array}{l}\text { Length of } \\
\text { Followup }\end{array}$ & Recurrences \\
\hline 1 & 23 & $\mathbf{M}$ & $\begin{array}{l}\text { Dementia, Chiasmal Syndrome } \\
\text { Optic Atrophy }\end{array}$ & 3 yrs. & $\begin{array}{l}\text { Chiasm to Posterior } \\
\text { Fossa }\end{array}$ & 30 yrs. & $3 X$ \\
\hline 2 & 28 & $\mathbf{F}$ & $\begin{array}{l}\text { Ataxia, Nausea, Vomiting } \\
\text { Diplopia }\end{array}$ & $1 \mathrm{yr}$. & $\begin{array}{l}\text { Cerebellopontine } \\
\text { Angle }\end{array}$ & 17 yrs. & $2 X$ \\
\hline 3 & 36 & $\mathrm{~F}$ & $\begin{array}{l}\text { Ataxia, Nausea, Vomiting } \\
\text { Diplopia }\end{array}$ & 4 yrs. & Cerebellum & 7 yrs. & $1 X$ \\
\hline 4 & 44 & $\mathrm{~F}$ & Headache, Decreased Vision & 6 mos. & L Frontal Lobe & $11 \mathrm{yrs}$ & - \\
\hline 5 & 52 & $\mathrm{~F}$ & $\begin{array}{l}\text { Lethargy, Anorexia } \\
\text { Incontinence }\end{array}$ & 2 yrs. & Bifrontal & 14 yrs. & $1 X$ \\
\hline 6 & 67 & M & $\begin{array}{l}\text { Ataxia, Nausea, Vomiting } \\
\text { Diplopia }\end{array}$ & 3 yrs. & Posterior Fossa & 15 yrs. & $1 X$ \\
\hline
\end{tabular}

Table l-Patients with histologically proven intracranial epidermoids (excluding those confined to the skull) observed at the Johns Hopkins Hospital over the last thirty years.

parasellar region, dermoids occur throughout the posterior fossa and at the base of the brain (Love and Kernohan, 1936; MaCarty et al., 1959). Brock and Klenke (1931) found a significant number of dermoids in the temporal lobe and commented on the frequency of seizures in these patients; however, in a series of one hundred consecutive patients with temporal lobe seizures, only one dermoid was found to be the etiologic lesion (Falconer et al., 1964). In the patient reported here, the site of origin was the base of the brain with gradual enlargement of the cyst into the left cerebral hemisphere (Fig. 5).

Differential diagnosis. The parasellar and posterior fossa locations of dermoids and epidermoids have resulted in some confusion with three similar lesions: (1) middle ear cholesteatomas; (2) craniopharyngiomas; and (3) Rathke's pouch cysts.
The confusion between intracranial epidermoid and dermoid tumors and middle ear cholesteatomas stems not only from the use of the term "cholesteatoma" to describe epidermoids but also from the controversy surrounding the nature and etiology of these lesions. Tumarkin (1957) originally proposed three potential mechanisms of origin of middle ear cholesteatomas: congenital inclusion of squamous epithelium; migration of squamous epithelium from the external ear into the middle eat through a perforated ear drum; and metaplasia of the normal epithelial lining of the middle ear secondary to chronic inflammation. Although some cholesteatomas may be related to pre-existing inflammation, Toglia (1965) strongly favors the inclusion theory, citing the fact that with the advent of antiobiotic therapy, the incidence of chronic otitis media has markedly diminished while the incidence of cholesteatomas has re- mained unchanged. Moreover, the presence of hair and glandular elements in some of these lesions also supports the inclusion theory since it would be most unusual for a postinflammatory change to incite the development of glandular structures in metaplastic squamous epithelium. If one accepts the congenital inclusion origin of cholesteatomas, then these lesions are indeed similar in both mechanism of origin and histologic appearance to true intracranial epidermoids and dermoids and perhaps should be regarded as such.

Cystic craniopharyngiomas and Rathke's pouch cysts may be mistaken for epidermoids; however, they are derived from epithelium of the mouth. They contain no stratum granulosum and therefore show no keratinization. This feature alone serves to differentiate them from other types of epidermal masses although their mechanism of origin and growth by desquamation of

TABLE 2

\begin{tabular}{|c|c|c|c|c|c|c|c|}
\hline Case No. & $\begin{array}{l}\text { Age At } \\
\text { Onset }\end{array}$ & Sex & Symptomatology & $\begin{array}{l}\text { Duration To } \\
\text { Diagnosis }\end{array}$ & Location & $\begin{array}{l}\text { Length of } \\
\text { Followup }\end{array}$ & $\begin{array}{l}\text { Recur- } \\
\text { rences }\end{array}$ \\
\hline 1 & 37 & M & $\begin{array}{l}\text { Seizures, Irritability } \\
\text { Visual Field Defect }\end{array}$ & 7 yrs. & $\begin{array}{l}\text { L Cerebral } \\
\text { Hemisphere }\end{array}$ & l yr. & - \\
\hline 2 & 43 & M & $\begin{array}{l}\text { Seizures, Aphasia } \\
\text { Headache, Somnolence }\end{array}$ & 7 yrs. & $\begin{array}{c}\text { L Temporal } \\
\text { Fossa }\end{array}$ & 3 mos. & - \\
\hline 3 & 52 & $\mathrm{~F}$ & $\begin{array}{l}\text { Lethargy, } \\
\text { Right Hemiparesis } \\
\text { Visual Field Defect }\end{array}$ & $1 \mathrm{yr}$. & $\begin{array}{l}\text { L Parieto- } \\
\text { Occipital Area }\end{array}$ & $16 \mathrm{yrs}$. & $\mathrm{X} 1$ \\
\hline
\end{tabular}

Table 2-Patients with histologically proven intracranial dermoids observed at the Johns Hopkins Hospital over the last thirty years. 


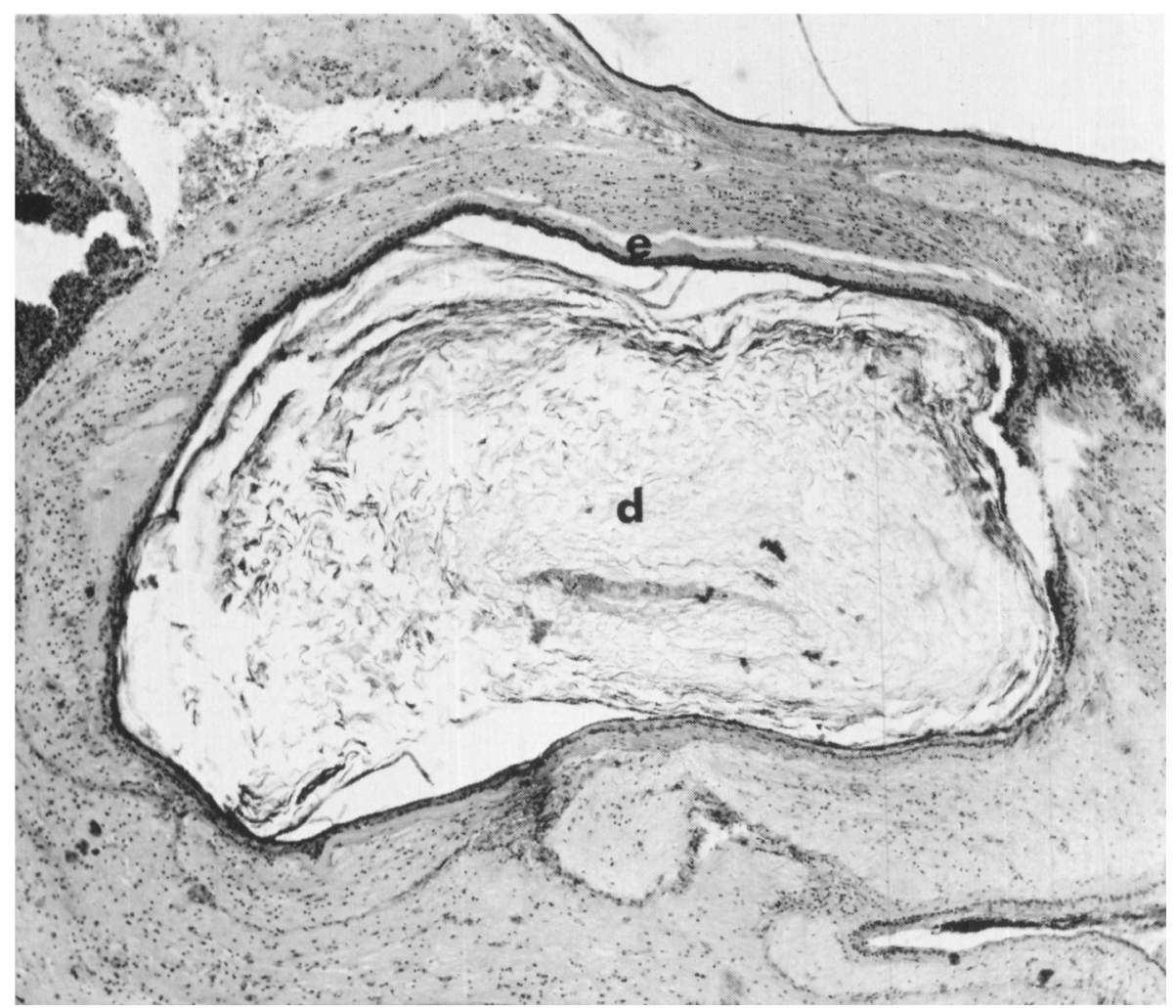

Figure 8-Epidermoid cyst with thin epithelial lining (e) and acellular debris (d) within the cyst cavity. ( $H \& E, X 45)$.

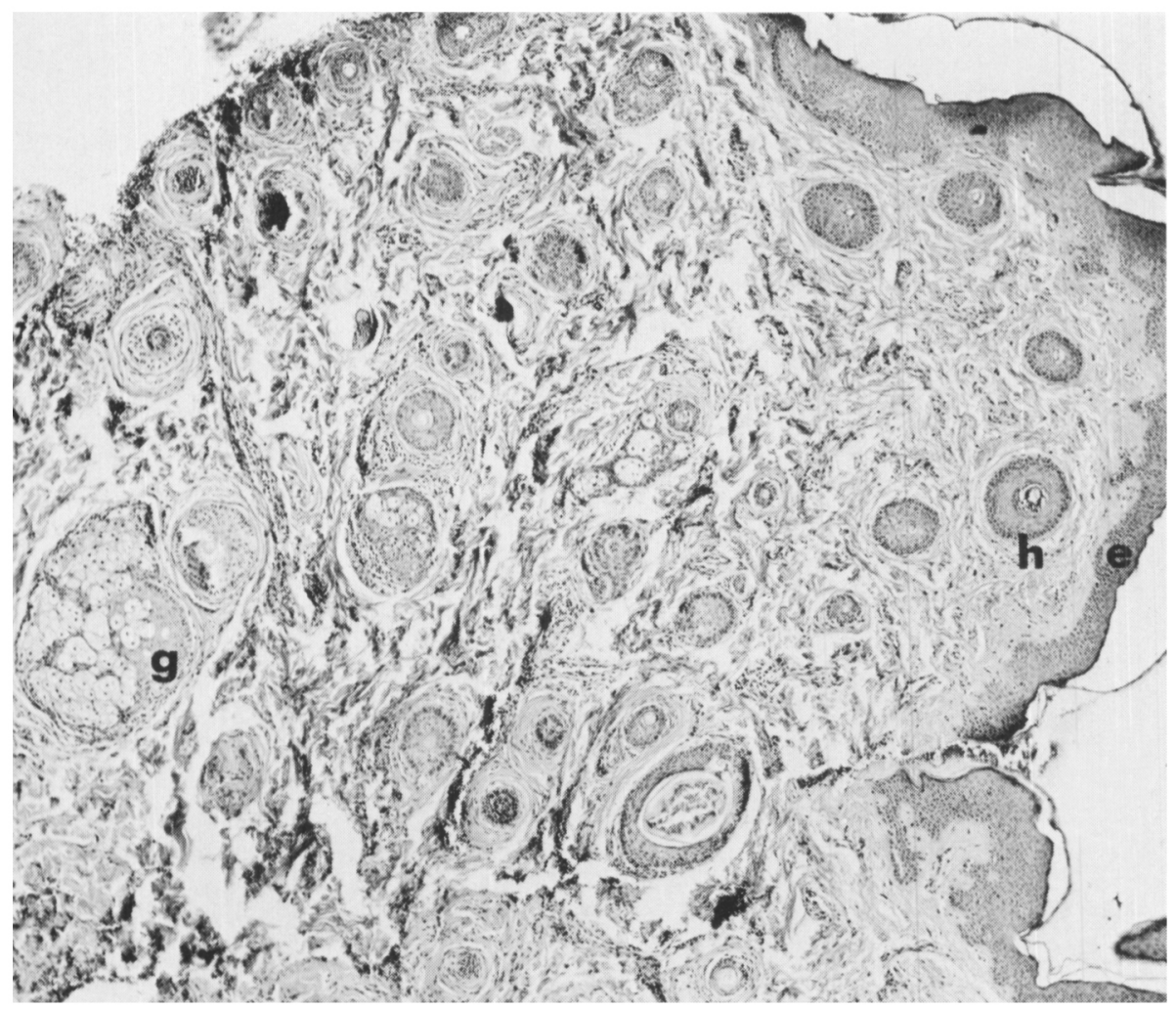

Figure 9-Dermoid cyst with keratinized epithelial lining (e), numerous hair shafts (h) and epithelial glands (g). (H \& E, X45). epithelial cells are identical to those of "true" intracranial epidermoids and dermoids.

Treatment. The management of intracranial dermoids and epidermoids is often difficult owing to their widespread, firm adherence to meninges and normal cerebral tissue, as in our patient. It is generally acknowledged that complete removal is rarely possible and that intracapsular curettage and irrigation of the cyst cavity is the preferred mode of surgical treatment (Love and Kernohan, 1936; Dándy, 1942; Mark et al., 1960); however, in irrigation of the cyst, leakage of contents into the ventricular system may result in a severe, aseptic meningitis (Tytus and Pennybacker, 1956; Zylak et al., 1969).

Because most of these lesions are incompletely excised leaving the epithelial cells lining the cyst wall to continue the process of keratinization and desquamation, recurrence of these tumors is common and frequent followup of all patients is mandatory. Of the nine patients who have been operated at the Johns Hopkins Hospital over the last thirty years, six have had recurrences of their tumors. Our patient has been followed for one year without evidence of recurrence.

The authors gratefully acknowledge the assistance of Frank B. Walsh, M.D., Kenneth R. Kenyon, M.D., and John W. Chambers, M.D., in the preparation of this manuscript.

\section{REFERENCES}

BOGDANOWICZ, W, M and WILSON, D. H. (1972). Dermoid cyst of the fourth ventricle demonstrated on brain scan. J. Neurosurg. 36: 228-230.

BOSTROEM, R. (1897). Uber die pialen Epidermoide, Dermoide, und Lipome und duralen Dermoide. Centralbl. f. allg. Path. u. path. Anat. viii: 1-30.

BROCK, S. and KLENKE, D. A. (1931). A Case of Dermoid Overlying the Cerebellar vermis. Bull. Neurol. Inst. New York I: 328-342.

CRITCHLEY, M. and FERGUSON, F. R. (1928). The cerebrospinal epidermoids (cholesteatoma). Brain 51: 334-384.

CRUVEILHIER, J. (1829). Anatomie pathologique du corps humain. Paris, J. B. Bailliere, 1: book 2, plate 6, 341 .

CUSHING, H. (1932). "Intracranial Tumors: Notes upon a Series of Two Thousand 
Verified Cases with Surgical-Mortality Percentages Pertaining Thereto."' Springfield, Ill., Charles C. Thomas, publ.

DANDY, W. E. (1942). "Practice of Surgery" ed. D. D. Lewis; Vol. 12: 626-634. Hagerstown, Md., W. F. Prior, publ.

FALCONER, M. A., SERAFETINIDES, E. A., and CORSELLIS, J. A. N. (1964). Etiology and Pathogenesis of Temporal Lobe Epilepsy. Arch. Neurol. 10: 233-248.

FLEMING, F. R. and BOTTERELL, E. H. (1959). Intracranial Dermoid and Epidermoid Tumors. Surg. Gynec. Obst. 109: 403-411.

FOX, H. and SOUTH, E. A. (1965). Squamous cell carcinoma developing in an intracranial epidermoid cyst (cholesteatoma). J. Neurol. Neurosurg. Psychiat. 28: 276-281.

KEVILLE, F. J. and WISE, B. L. (1959). Intracranial Epidermoid and Dermoid Tumors. J. Neurosurg. 16: 564-569.

LOVE, J. G. and KERNOHAN, J. W. (1936). Dermoid and Epidermoid Tumors (Choles- teatomas) of the Central Nervous System. J.A.M.A. 107: 1876-1883.

MaCARTY, C. S., LEAVENS, M. E., LOVE, J. G. and KERNOHAN, J. W. (1959). Dermoid and Epidermoid Tumors in the Central Nervous System. Surg. Gynec. Obst. 108: 191-198.

MARK, V. H., SMITH, J. L., and KJELLBERG, R. D. (1960). Suprasellar epidermoid tumor. A case report with the presenting complaint of see-saw nystagmus. Neurology 10: 81-83.

MULLER, J. (1838). Ueber den feinern Bau und die Formen der krankhaften Geschwulste. Reimer, Berlin.

RAND, C. S. and REEVES, D. L. (1943). Dermoid and epidermoid tumors (cholesteatomas) of the central nervous system. Report of twenty-three cases. Arch. Surg. 46: $350-370$.

RUSSELL, D. S. and RUBENSTEIN, L. (1971). Pathology of Tumors of the Nervous System. Third Edition. Baltimore, Md., Williams and Wilkins, publ., pp. 10-16.
TOGLIA, J. U., NETSKY, M. G., and ALEXANDER, E. (1965). Epithelial (Epidermoid) Tumors of the Cranium. J. Neurosurg. 23: 384-393.

TUMARKIN, A. (1957). On the nature and vicissitudes of the accessory air spaces of the middle ear, part V. J. Lar. Otol. 71: 211-248.

TYTUS, J. S. and PENNYBACKER, J. (1956). Pearly Tumors in Relation to the Central Nervous System. J. Neurol. Neurosurg. Psychiat. 19: 241-259.

ULRICH, J. (1964). Intracranial Epidermoids. A study on their distribution and spread. J. Neurosurg. 21: 1051-1058.

VIRCHOW, R. (1855). Ueber Perlgeschwulste. (Cholesteatoma Joh Muller's.) Virchows Arch. path. anat, 8: 371-418.

ZYLAK, C. J., CHILDE, A. E., ROSS, R. T., and PARKINSON, D. (1969). Lucent Unilateral Supratentorial Dermoid Cyst. Report of an Unusual Case. Amer. J. Roentgenol. 106: 329-332. 